\title{
A Cross-Sectional Evaluation on Physical Fitness of Malaysian Firefighters
}

\author{
(Suatu Penilaian Rentas Lintang Kecergasan Fizikal Ahli Bomba Malaysia)
}

\author{
ATIKAH, C.W., NiHAYAH, M.*, LEONARD, J.H., OMAR, B., NOOR IBRAHIM, M.S .,
} ZURKARNAIN, M.K., JAMRI, M. \& WAN MOHD NOOR, I.

\begin{abstract}
Fire fighting is one of the most strenuous activities in the hazardous fire service industry. Firefighters have to be physically fit in order to provide an effective and safe fire prevention to the afflicted community and as well as to themselves. The aimed of this cross-sectional study was to evaluate the physical fitness among Malaysian firefighters. The hand grip test to evaluate hand and muscular strength was measured using hand dynamometer and one-minute sit ups and one-minute push ups were conducted to measure abdominal muscle endurance. The sit and reach test was carried out to measure lower back and hamstring flexibility. $\mathrm{VO}_{2}$ max was assessed by a 20 meter shuttle run test to measure cardiorespiratory fitness. A total of 385 subjects were participated and the results showed that $77.1 \%(\mathrm{n}=297)$ and $84.8 \%(\mathrm{n}=325)$ of them had very poor scores for hand grip strength and $\mathrm{VO}_{2}$ max, respectively. For one-minute sit ups, $40.8 \%(\mathrm{n}=157)$ of subjects scored excellent. Meanwhile, $32.7 \%(\mathrm{n}=126)$ subjects scored average for one-minute push ups. For flexibility test, $53.2 \%$ $(\mathrm{n}=205)$ subjects had poor flexibilty. The results showed there were significantly difference between one-minute sit ups $(\mathrm{p}<0.001)$, one-minute push ups $(\mathrm{p}<0.05)$, flexibility $(\mathrm{p}<0.05)$ and $\mathrm{VO}_{2} \max (\mathrm{p}<0.001)$ according to age. As a conclusion, this study provides representative data on physical fitness among Malaysian firefighters. These findings suggested the needs to explore the issues behind low physical fitness among Malaysian firefighters and to find ways to improve them.
\end{abstract}

Keywords: Cardiorespiratory fitness; firefighters; Malaysia; muscle endurance; muscle strength; physical fitness

\section{ABSTRAK}

Memadam kebakaran adalah salah satu aktiviti berat dalam industri perkhidmatan bomba yang berbahaya. Anggota bomba perlu mempunyai fizikal yang sihat untuk memberi perkhidmatan pencegahan kebakaran yang berkesan dan selamat kepada masyarakat terlibat dan juga diri mereka sendiri. Kajian rentas lintang ini bertujuan untuk menilai kesihatan fizikal dalam kalangan anggota bomba di Malaysia. Ujian genggaman tangan untuk menilai kekuatan tangan dan otot diukur menggunakan dinamometer tangan serta bangkit tubi dan tekan tubi masing-masing satu minit dijalankan untuk mengukur daya tahan otot abdomen. Ujian duduk dan jangkau telah dijalankan untuk mengukur kefleksibelan bahagian belakang dan hamstring. $\mathrm{VO}_{2}$ max dinilai melalui ujian larian ulang-alik 20 meter untuk mengukur kesihatan pernafasan kardio. Seramai 385 subjek telah mengambil bahagian dan keputusan menunjukkan bahawa $77.1 \%(\mathrm{n}=297)$ dan $84.8 \%(\mathrm{n}=325)$ mempunyai skor yang rendah masing-masing untuk kekuatan genggaman tangan dan $\mathrm{VO}_{2}$ max. Bagi satu minit bangkit tubi pula, 40.8\% ( $\mathrm{n}=157)$ subjek memperoleh markah cemerlang. Sementara itu, 32.7\% $(\mathrm{n}=126)$ subjek memperoleh skor sederhana untuk satu minit tekan tubi. Bagi ujian kefleksibelan pula, 53.2\% (n=205) subjek mempunyai kefleksibelan yang rendah. Keputusan menunjukkan terdapat perbezaan yang ketara antara satu minit bangkit tubi $(\mathrm{p}<0.001)$, satu minit tekan tubi $(\mathrm{p}<0.05)$, kefleksibelan $(\mathrm{p}<0.05)$ dan $\mathrm{VO}_{2}$ max $(\mathrm{p}<0.001)$ mengikut umur. Kesimpulannya, kajian ini menyediakan data wakilan untuk kesihatan fizikal dalam kalangan anggota bomba Malaysia. Kajian ini mencadangkan keperluan untuk mengkaji isu di sebalik kesihatan fizikal yang rendah dalam kalangan anggota bomba Malaysia dan mencari jalan untuk memperbaiki keadaan ini.

Kata kunci: Bomba; kekuatan otot; kesihatan fizikal; kesihatan pernafasan kardio; ketahanan otot; Malaysia

\section{INTRODUCTION}

Firefighters face a physically demanding activities such as rescue and fire supression and all these are carried out while wearing heavy personal protective equipment. Kiss et al. (2014) pointed out firefighters have to be physically fit to be exposed to the demands of their occupational and psychosocial roles. Perry (2013) stated that physical fitness is the ability of a person's body to give an efficient function while working, doing leisure activities and during emergency situations. However, Caspersen et al. (1985) noted that physical fitness is different than physical activity whereby it is defined as a set of physical attributes that everyone has to achieve.

Health related components of physical fitness are muscular strength, muscular endurance, flexibility and cardiorespiratory fitness (Caspersen et al. 1985). Muscular strength refers to the ability of hand and forearm to exert the external force (Corbin 1981). Muscular strength is vital for 
firefighters who are often involved in fire fighting activities (Kiss et al.2014). According to Murugan et al. (2013), hand functionality is important in activities involving upper limb including carrying and lifting objects. Hand grip strength is one of the tests to measure muscular strength specific to a muscle group such as flexor muscle (Wilmore 1989). Most strenous activities require adequate hand grip in order to give better performance and prevent injuries (Murugan et al. 2013).

In order for firefighters to sustain their fire fighting activities for long period of time, they have to have functional muscular endurance. Muscular endurance is the ability of muscle to exert external force when there are repetitive successive exertions (Hopson et al. 2012). Muscular endurance is important in reducing risk of injury. Whereby a failure in sustaining muscular endurance may lead to upper or lower injuries including the trunk flexor (Hopson et al. 2012). Sit ups and push ups are health related tests that are commonly performed to measure muscular endurance (Waldhelm \& Li 2012).

Joint functionality is very important when firefighters are at the fireground where they are required to have reasonable flexibility to manoeuvre in and out of the situations. Flexibility is one of the test to measure the health state of a joint (Harris 1969). According to Arregui Erana \& Martinez de Haro (2001), flexibility is one of the component of physical fitness which is important to produce a maximal range of motions when using a joint or a series of joints. The upper body flexibility is important for reaching objects, while the lower body flexibility is important for walking, bending and reaching objects (Spiriduso et al. 2005). Corbin (1981) stated that cardiorespiratory fitness is the ability of the circulatory and respiratory system to supply fuel during a sustained physical activity and to eliminate fatigue products. Poor cardiorespiratory fitness is the major component of physical fitness that is related to the development of cardiovascular diseases (Haskell \& Kiernan 2000).

Levels of physical fitness can be influenced by many factors including age. According to Ortega et al. (2008), physical fitness has been proven as a major marker of health related status in younger and older people. Jackson et al. (2009) pointed out that cardiorespiratory fitness in adults decreases with age. As people grew older, the amount of blood that the heart can pump decreases during maximal exercise. This condition will lowers individual's physical fitness. Morever, the body weight of the older people will increases while the muscle mass decreases. As a result, the muscular strength, muscular endurance, flexibility and cardiorespiratory fitness will decrease.

Physical fitness is a crucial factor that influences the effective performance of firefighters and prevention against injuries. A study on the current physical fitness of firefighters is important to help health practitioners and employers to identify problems related to it and such informations are needed to develope and implement wellness programme. Hence, this study aimed to evaluate the physical fitness among Malaysian firefighters.

\section{METHODS}

This study was approved by Universiti Kebangsaan Malaysia Research Ethics Committee (UKM 1.5.3.5/244/ NN-069-2014). There were 385 male firefighters involved in this study. The inclusion criteria were firefighters aged between 20 to 46 years old, work full time on field and have at least minimum of two years experience and services. Meanwhile, exclusion criteria were firefighters who had previous history of any systemic diseases or had musculoskeletal injuries. Subjects were given brief explanations about the study procedures and consent form was obtained prior to their participation in this study.

\section{MATERIALS AND METHODS}

\section{HAND GRIP TEST}

Hand dynamometer (Sammon Jamar Hydraulic Hand Dynamometer 5030J1, Georgia) was used for measuring hand and forearm muscular strength. The procedures of hand grip test was adapted from Roberts et al. (2011). Subjects were asked to grip the dynamometer as maximum as they can according to their own comfort. There were dual scale readout of forces which are kilograms $(\mathrm{kg})$ and pounds (lb). However all the average readings were recorded in $\mathrm{kg}$. The cut off value for evaluating the scores for handgrip test was adopted from Davis et al. (2000).

\section{ONE-MINUTE PUSH UPS AND SIT UPS, RESPECTIVELY}

One-minute push ups was performed to measure abdominal muscular endurance. Subjects placed their both hands slighly wider than the shoulder width on the flat surface and the fingers were pointed forward. They were noted to not cross their feet. From that position, the subjects were asked to lower their body until the upper arms were parallel to the ground to lower position. The subjects were then returned to the original position until the elbows were extended. This step was counted as one repitition. The score was recorded by counting the correct push ups that has been done in one-minute.

One-minute sit ups has also been used for the endurance test. Subjects lying on their back with the knees bent and the heels flat on the floor. The fingers were placed behind the head to interlock them. The buttocks were maintained on the floor without giving tension to the hips. One of the colleague helped to hold the subject's feet. Coming up, the elbows must touch the knees and continue with a full lying to start the next sit ups. In the down position, the shoulder must touch the ground. The score was recorded by counting the correct sit ups that has been completed in one-minute. The cut off points for determining the scores for both one-minute push ups and sit ups, respectively, were referred from the study that has been done by Golding et al. (1986). This scores were classified into three different age groups whereby each group had their on specific levels of achievement. 


\section{FLEXIBILITY TEST}

Sit and reach test was used for measuring back and lower body flexibility. Subjects sat on the flat floor with the bare feet touched on the base of the box. The knees should be flat on the floor and were avoided from pulled up. Hands were placed on top of the flat surface on the box where the palms were facing downwards. Subjects were asked to push their body forward so that their hands can push the marker along the measuring line as far as they can. The distance reached by the subjects were recorded in centimeter (Wells $\&$ Dillon 1952). The test was repeated three times in order to get the average. There were five scores for sit and reach test which were excellent, good, average, poor and very poor. All the cut off points for these scores were adopted from Davis et al. (2000).

\section{CARDIORESPIRATORY ENDURANCE TEST}

The gold standard for the cardiorespiratory fitness is maximal oxygen uptake or power $\left(\mathrm{VO}_{2} \mathrm{max}\right.$ ) (Haskell $\&$ Kiernan 2000). In this study, the 20 meter shuttle run test (20-MST) was applied for estimating the $\mathrm{VO}_{2}$ max (Sproule et al. 1993). Subjects were required to run in 20 meter between two lines with the help of the recorded beeps. When the first beep was signaled, the subjects started to begin their run from the first cone to the second cone. Subjects were adviced to start their run at slow speed because after one minute, the beeps were closer together where it was indicated that the speed was increased. If the subject reached the cone before the beep sound was popped out, they have to wait before continuing. After the second beep signaled, subjects continued their run back to the first cone. This running continued subsequently until the subjects failed to reach the cone before the beep sounded after two consecuative warning. Every level that has been completed by the subject was recorded. Value for $\mathrm{VO}_{2}$ max was calculated by using a formula proposed by Flouris et al. (2005).

$$
\mathrm{VO}_{2} \max =31.025+3.238 \mathrm{X}-3.248 \mathrm{~A}+0.1536 \mathrm{AX},
$$

where, $\mathrm{X}$ is the speed $\left(\mathrm{km} \cdot \mathrm{h}^{-1}\right)$ (according to levels of achievement) and $\mathrm{A}$ is the age

The cut off points for evaluating levels of $\mathrm{VO}_{2} \max$ was determined using the reference from Heywood (2006) whereby the scores were stated according to individual's age.

\section{STATISTICAL ANALYSIS}

The Statistical Package for The Social Sciences version 20.0 was used to create database suitable for this study. Descriptive analysis was used for the demographic data and status of physical fitness. Meanwhile, one way ANOVA was used to compare the components of physical fitness according to age. Further post hoc analysis using Bonferroni was applied to find the significant value between groups.

\section{RESULTS}

The findings showed the percentage of firefighters aged between 29-37 years old (48.8\%) was highest compared with firefighters aged between 20-28 years old (37.9\%) and 38-46 years old (13.2\%). Meanwhile, $91.9 \%$ of them were Malay firefighters (Table 1).

A total of $77.1 \%$ of firefighters had very poor score for the total handgrip. While, there were only 3.1 and $5.5 \%$ of firefighters had good and excellent score, respectively. The results showed that there were $40.8 \%$ of firefighters achieved an excellent score for one-minute sit ups test and the least was the firefighters who had very poor score (3.9\%). However, for one-minute push ups test, most firefighters $(32.7 \%)$ scored average followed by good score $(25.5 \%)$. Meanwhile, for sit and reach test, there were $53.2 \%$ of firefighters has poor score and only $3.4 \%$ have excellent score. For cardiorespiratory fitness, most of the firefighters $\left(84.4 \%\right.$ ) had very poor $\mathrm{VO}_{2}$ max value. While for excellent score, there were only $0.3 \%$ firefighters who has achieved it (Table 2).

The results showed there were significantly higher $(p<0.001)$ mean value of one-minute sit ups for firefighters aged between 20-28 years old compared with the other two age groups. However, there were significantly lower $(p<0.05)$ mean value of one-minute push ups for firefighters aged between 29-37 years old and 38-46 years old compared with those who aged between 20-28 years old. For sit and reach test, there was significantly lower $(p<0.05)$ mean value for firefighters aged between 38-46 years old compared with the other two age groups. Meanwhile, mean value of $\mathrm{VO}_{2}$ max for firefighters aged between 20-28 years old was significantly higher compared with firefighters aged between 29-37 years old and 38-46 years old (Table 3 ).

TABLE 1. Demographic data of firefighters

\begin{tabular}{lcccc}
\hline & \multicolumn{4}{c}{ Demographic data $n=385$} \\
\hline Age (Years) & $20-28$ & $29-37$ & $38-46$ & \\
& $(n=122)$ & $(n=176)$ & $(n=87)$ & \\
Percentage (\%) & 31.7 & 45.7 & 22.6 & Others \\
Race & Malay & Chinese & Indian & $(n=26)$ \\
& $(n=354)$ & $(n=3)$ & $(n=2)$ & 6.8 \\
\hline
\end{tabular}


TABLE 2. Scores of physical fitness for each tests

\begin{tabular}{|c|c|c|c|c|c|}
\hline \multirow[t]{2}{*}{ Activities } & \multicolumn{5}{|c|}{ Number of firefighters $(\%)(n=385)$} \\
\hline & Excellent & Good & Average & Poor & Very Poor \\
\hline \multicolumn{6}{|l|}{ Muscle strength } \\
\hline Total hand grip $(\mathrm{kg})$ & 5.5 & 3.1 & 5.2 & 9.1 & 77.1 \\
\hline \multicolumn{6}{|l|}{ Muscle endurance } \\
\hline One-minute sit ups (reps) & 40.8 & 34.8 & 10.6 & 9.9 & 3.9 \\
\hline $\begin{array}{l}\text { One-minute push } \\
\text { ups (reps) }\end{array}$ & 13.0 & 25.5 & 32.7 & 20.3 & 8.6 \\
\hline \multicolumn{6}{|l|}{ Flexibility } \\
\hline Sit and reach test $(\mathrm{cm})$ & 3.4 & 0 & 14.0 & 53.2 & 29.4 \\
\hline \multicolumn{6}{|l|}{ Cardiorespiratory fitness } \\
\hline $\mathrm{VO}_{2} \max (\mathrm{mL} / \mathrm{mg} / \mathrm{min})$ & 0.3 & 0.5 & 3.9 & 10.9 & 84.4 \\
\hline
\end{tabular}

TABLE 3. Mean value of physical fitness according to age

\begin{tabular}{|c|c|c|c|c|}
\hline & \multicolumn{3}{|c|}{$\begin{array}{l}\text { Mean } \pm \text { SD } \\
\text { Age (Years) }\end{array}$} & \multirow[t]{2}{*}{$\mathrm{p}$-value } \\
\hline & $20-28$ & $29-37$ & $38-46$ & \\
\hline Total hand grip (kg) & $83.47 \pm 20.34$ & $88.00 \pm 17.56$ & $84.24 \pm 17.33$ & 0.081 \\
\hline One-minute sit ups (reps) & $39.17 \pm 8.33$ & $36.30 \pm 7.80^{\mathrm{a}}$ & $32.70 \pm 8.81^{\mathrm{a}}$ & $<0.001$ \\
\hline One-minute push ups (reps) & $33.67 \pm 11.81$ & $30.68 \pm 13.54^{\mathrm{b}}$ & $30.30 \pm 11.52^{\mathrm{b}}$ & $<0.05$ \\
\hline Sit and reach test $(\mathrm{cm})$ & $34.46 \pm 6.76$ & $34.58 \pm 10.39$ & $31.81 \pm 7.06^{\mathrm{d}}$ & $<0.05$ \\
\hline $\mathrm{VO}_{2 \max }(\mathrm{mL} / \mathrm{mg} / \mathrm{min})$ & $28.28 \pm 5.55$ & $26.06 \pm 4.65$ & $24.89 \pm 4.82^{\mathrm{c}}$ & $<0.001$ \\
\hline
\end{tabular}

a,b,c There is significant difference compared to the age group of 20-28 years old

There is significant difference $(p<0.05)$ compared to the age group of 20-28 and 29-37 years old

\section{DISCUSSION}

Most of firefighters had very poor score for handgrip test. This condition occured because of the frequent heavy activities that oftenly performed by firefighters. According to Dohi et al. (2001), heavy works will reduced the lymphocyte proliferative responses in the muscle and it will lowers hand functionality. The daily firefighting activities such as holding and lifting hose involved the upper limb. Therefore, it is important for them to have good hand grip strength (Murugan et al. 2013). The failure in forcing the maximum capabilities of the muscle can cause the person to have musculoskeletal disorders (Roman-Liu \& Tokarski 2005).

The results showed firefighters who had excellent scores for one-minute sit ups were higher compared with one-minute push ups. One-minute push ups test involved pectoralis muscle. If there is any weaknesses involving this muscle, it will lower the muscle endurance. According to Leonard et al. (2014), the prevalence of firefighters who complaint of having musculoskeletal injuries at the shoulder region were high due to heavy hose they carried during firefighting activities. Firefighters tend to have high risk of ergonomic muskuloskeletal injuries caused by the improper way on how to carry the hose.

The percentage of having poor flexibility was the highest. When reaching the fireground, movement or mobility of the firefighters become more restricted due to heavy personal protective equipment that was carried out by them. In order to counteract this situation, it is important for the firefighters to be more flexible by increasing the flexibility. People are vulnerable to get injury such as back pain if they were unable to maintain their flexibility (Moore 2014).

There was no significant difference for the value of total hand grip strength according to age. This result was contradicted with the study by Espana-Romero et al. (2008) where they concluded that the handgrip strength was influenced by age. At the age of 20 to 35 years old, the muscle strength increases and after 35 years old it will decreases (Lynch et al. 1999). According to Murata et al. (2010), as the human grow older, function of their hand will be decreased and this happened due to the changes of hand muscle. However, there was another study which stated that the handgrip strength can also be influenced by the position of the elbow and the size of hand (EspanaRomero et al. 2010; Murugan et al. 2013).

The results showed that the muscular endurance is significantly decrease for one-minute sit ups and push ups, respectively, as the age increases. According to Thompson (1994), decreasing in muscle endurance among older people was caused by increasing in the level of fatigue. Katsiaras et al. (2005) stated that failure in maintaining the tension of muscle can decrease muscular endurance caused by fatigue. This study showed that there was a decrease in mean value of flexibility as the age increases. This result 
was in line with the study by Valdivia et al. (2008). The decrease in flexibility among older people is related with the decreasing in the number of connective tissue present in the muscle. The release of estrogens and androgens cause the flexibilty to decrease and become more limited as the human grow older (Valdivia et al. 2008).

The mean value of $\mathrm{VO}_{2} \max$ was significantly higher among firefighters aged between 21-28 years old compared with the other groups. This result was supported by the study of Thompson (1994) where the amount of $\mathrm{VO}_{2} \max$ is lower in older people. This condition occurred due to decrease in muscle mass. The reduction in muscle mass will lower the consumption of oxygen in muscle (Thompson 1994). A study by Gothi et al. (2010) stated that age will influence the cardiorespiratory fitness by reducing value of $\mathrm{VO}_{2}$ max. Hence, it is necessary for firefighters to sustain the $\mathrm{VO}_{2}$ max as it can eliminates fatigue product during fire fighting activities (Corbin 1981).

\section{CONCLUSION}

This study showed that the physical fitness among firefighters was at low level. The findings also showed there were decreased in the component of physical fitness as the age increased. The initiatives to develop module of the fitness programme should be implemented to improve the wellness among firefighters. Further studies are needed in order to identify the confounding factors that influence the physical fitness and risk factors of having low physical fitness.

\section{ACKNOWLEDGEMENTS}

This study was funded by Industri-2013-014 Grant. The authors are grateful for the participation and in kind support from The Fire and Rescue Department of Malaysia and everyone who contributed directly or indirectly to this research.

\section{REFERENCES}

Arregui Erana, J.A. \& Martinez de Haro, V. 2001. Current state of research on flexibility in adolescents. International Medical Journal of Science of Physical Activity and Sport 1: 127-135.

Caspersen, C.J., Powell, K.E. \& Christenson, G.H. 1985. Physical activity, exercise, and physical fitness: Definitions and distinctions for health-related research. Public Health Reports 100(2): 126-131.

Corbin, C.B. 1981. Concepts in Physical Education, with Laboratories and Experiments. 4th ed. Dubuque, Iowa: W.C. Brown Co. pp. 314-323.

Davis, B., Bull, R., Roscoe, J. \& Roscoe, D. 2000. Physical fitness and fitness testing. Physical Education and the Study of Sport. 4th ed. New York: Mosby. pp. 123.

Dohi, K., Mastro, A.M., Miles, M.P., Bush, J.A., Grove, D.S., Leach, S.K., Volek, J.S., Nindl, B.C., Marx, J.O., Gotshalk, L.A., Putukian, M., Sebastianelli, W.J. \& Kraemer, W.J. 2001. Lymphocyte proliferation in response to acute heavy resistance exercise in women: Influence of muscle strength and total work. European Journal of Applied Physiology 84(3-4): 367-373.

Espana-Romero, V., Ortega, F.B., Vicente-Rodriguez, G., Artero, E.G., Rey, J.P. \& Ruiz, J.R. 2010. Elbow position affects handgrip strength in Adolescents: Validity and reliability of Jamar, DYnex, and TKK dynamometers. Journal of Strength and Conditioning Research 24(1): 272-277.

Espana-Romero, V., Artero, E.G., Santaliestra-Pasias, A.M., Gutierrez, A., Castillo, M.J. \& Ruiz, J.R. 2008. Hand span influences optimal gripspan in boys and girls aged 6 to 12 Years. Journal of Hand Surgery 33: 373-384.

Flouris, A.D., Metsios, G.S. \& Koutedakis, Y. 2005. Enhancing the efficacy of the $20 \mathrm{~m}$ multistage shuttle run test. $B r . J$. Sports Med.39: 166-170.

Golding, L.A., Myers, C.R. \& Sinning, W.E. 1986. Y's Way to Physical Fitness: The Complete Guide to Fitness Testing and Instruction. USA: Human Kinetics. p. 3.

Gothi, J.L., Silawat, N. \& Savalia, J. 2010. Comparative study of cardio-vascular endurance, flexibility and body composition parameters of male physical education teachers of different districts in Gujarat. Journal of Exercise Science and Physiotherapy 6(2): 91-93.

Harris, M.C. 1969. A factor analytic study of flexibility. Res $Q$. 40: 62-70.

Haskell, W.L. \& Kiernan, M. 2000. Methodologic issues in measuring physicalactivity and physical fitness when evaluating the role of dietary supplements for physically active people. The American Journal of Clinical Nutrition 72(2): 541S-550S.

Heywood, V. 2006. The physical fitness specialist manual, The Cooper Institute for Aerobics Research, Dallas TX, revised 2005. In Advanced Fitness Assessment and Exercise Prescription, edited by Heywood, V. Champaign, IL: Human Kinetics. p. 5.

Hopson, J.L., Donatelle, R.J. \& Littrell, T.R. 2012. Building muscular strength and endurance. Get Fit, Stay Well!. 2nd ed. New York: Pearson Education. pp. 1-56.

Jackson, A.S., Sui, X., Hebert, J.R., Church, T.S. \& Blair, S.N. 2009. Role of lifestyle and aging on the longitudinal change in cardiorespiratory fitness. Arch. Intern. Med. 169(19): 1781-1787.

Katsiaras,A.,Newman,A.B., Kriska,A., Brach,J.,Krishnaswami, S., Feingold, E., Kritchevsky, S.B., Li, R., Harris, T.B., Schwartz,A.\& Goodpaster, B.H. 2005. Skeletal muscle fatigue, strength and quality in the elderly: The health ABC study. Journal of Applied Physiology 99: 210-216.

Kiss, P., De Meester, M., Maes, C., De Vriese, S., Kruse, A. \& Braeckman, L. 2014. Cardiorespiratory fitness in a representative sample of Belgian firefighters. Occupational Medicine 64(8): 589-594.

Lynch, N.A., Metter, E.J., Lindle, R.S., Fozard, J.L., Tobin, J.D., Roy, T.A., Fleg, J.L. \& Hurley, B.F. 1999. Muscle quality. I. Age-associated differences between arm and leg muscle groups. J. Appl. Physiol. 86: 188-194.

Leonard, H.J., Mohd Redzuan, M. \& Nihayah, M. 2014. Prevalence of musculoskeletal and ergonomic risk factors among firefighters in Klang Valley. Bachelor's Thesis. Universiti Kebangsaan Malaysia (Unpublished).

Moore, K. 2014. The Big Myth about Flexibility and Firefighter Back Injuries. http://www.fitfordutyconsulting.com/2014/03/ the-big-myth-about-flexibility-and-firefighter-back-injuries/. Accessed on 20 July 2014. 
Murugan, S., Patel, D., Prajapati, K., Ghoghari, M. \& Patel, P. 2013. Grip strength changes in relation to different body postures, elbow and forearm positions. International Journal of Physiotherapy and Research 1(4): 116-121.

Murata, J., Murata, S., Hiroshige, J., Ohtao, H., Horie, J. \& Kai, Y. 2010. The influence of age related changes in tactile sensibility and muscular strength on hand function in older adult females. International Journal of Gerontology 4: 180-183.

Ortega, F.B., Ruiz, J.R., Castillo, M.J., Moreno, L.A., Urzanqui, A., Gonzales-Gross, M., Sjostrom, M. \& Gutierrez, A. 2008. Health-related physical fitness according to chronological and biological age in adolescents. The AVENA study. J. Sports Med. Phys. Fitness 48(3): 371-379.

Perry, M. 2013. Physical Fitness: What is Physical Fitness?. http://www.builtlean.com/2012/02/21/physical-fitness/. Accessed on 23 November 2013.

Roberts, H.C., Denison, H.J., Martin, H.J., Patel, H.P., Syddall, H., Cooper, C. \& Sayer, A.A. 2011. A review of measurement of grip strength in clinical and epidemiological studies: Towards a standardised approach. Age Ageing 40(4): 423-429.

Roman-Liu, D. \& Tokarski, T. 2005. Upper limb strength in relation to upper limb posture. International Journal of Industrial Ergonomics 35: 19-31.

Spiriduso, W.W., Francis, K. \& MacRae, P. 2005. Physical development and decline. In Physical Dimensions of Aging, edited by Spiriduso, W.W. Human Kinetics, Champaign, Ill, USA. p. 2.

Sproule, J., Kunalan, C., McNeill, M. \& Wright, H. 1993. Validity of 20-MST for predicting VO2 max of adult Singaporean athelete. Br. J.Sp.Med.27(2): 202-204.

Thompson, L.V. 1994. Effects of age and training on skeletal muscle physiology and performance. Physical Therapy 74 71-81.

Valdivia, O.D., Canada, M.A.M., Martin, M.A., Ortega, F.Z., Rodriguez, J.A.\& Sanchez, M.F. 2008. Changes in flexibility according to gender and educational stage. Apunts. Med. Esport. 161: 10-17.

Waldhelm, A. \& Li, L. 2012. Endurance test is the most realiable core stability related measurement. Journal of Sport and Health Science 1: 121-128.
Wells, K.F. \& Dillon, E.K. 1952. The sit and reach.A test of back and leg flexibility. Research Quarterly 23: 115-118.

Wilmore, H.H. 1989. Design issues and alternatives in assessing physical fitness among apparently healthy adults in a health examination survey of the general population. In Assessing Physical Fitness and Physical Activity in Population-Based Surveys. Washington, DC: US DHHS Publication. pp. 891253.

Atikah, C.W., Nihayah, M.* \& Omar, B.

Programme of Biomedical Science

School of Diagnostic and Applied Health Sciences

Faculty of Health Sciences

Universiti Kebangsaan Malaysia

Jalan Raja Muda Abdul Aziz, 50300 Kuala Lumpur

Malaysia

Leonard, J.H.

Programme of Physiotherapy, School of Rehabilitations

Faculty of Health Sciences

Universiti Kebangsaan Malaysia

Jalan Raja Muda Abdul Aziz, 50300 Kuala Lumpur

Malaysia

Noor Ibrahim, M.S.,

Programme of Occupational Therapy, School of Rehabilitations Faculty of Health Sciences

Universiti Kebangsaan Malaysia

Jalan Raja Muda Abdul Aziz, 50300 Kuala Lumpur

Malaysia

Zurkarnain, M.K. \& Jamri, M. \& Wan Mohd Noor, I.

Fire and Rescue Department Malaysia

Malaysia

*Corresponding author; email: nihayahmohammad@gmail.com

Received: 13 May 2015

Accepted: 4 June 2015 